\title{
Pengaruh Ekstrak Bryophillum pinnatum Terhadap Jumlah Sel B Matur dan Kadar Anti dsDNA Pada Mencit BALB/c Model Lupus Bunting
}

\author{
Aminah Maya \\ Program Studi DIII Kebidanan STIKes Muhammadiyah Palembang \\ Jalan Jendral Ahmad Yani 13 Ulu Palembang \\ Email: mayachabie@gmail.com
}

\begin{abstract}
Abstrak
Latar Belakang : Systemic Lupus Eritematosus (SLE) adalah suatu penyakit autoimun kronis yang lebih banyak diderita oleh wanita terutama pada usia reproduktif. Penelitian in silico melalui molecular docking menemukan bahwa kandungan senyawa aktif yang dimiliki oleh tanaman cocor bebek (Bryophyllum pinnatum) memiliki potensi untuk dikembangkan menjadi terapi biosimilar.

Tujuan : Penelitian ini bertujuan melihat peran ekstrak daun Bryophillum pinnatum terhadap jumlah sel B matur dan kadar anti dsDNA pada mencit BALB/c model lupus bunting.

Metode : Rancangan penelitian yang digunakan adalah true experimental dengan pendekatan post test only control group design. Sampel penelitian ini adalah mencit galur BALB/c yang berjumlah 20 ekor, dan dikelompokkan menjadi 5 kelompok. Pengukuran Jumlah Sel B matur dilakukan dengan metode flowsitometri dan kadar anti dsDNA diukur dengan metode ELISA. Hasil: Jumlah sel B matur menunjukkan ada perbedaan yang bermakna pada kelima kelompok sampel dengan Pvalue $=0.029$, dilanjutkan dengan uji LSD dan didapatkan hasil ada perbedaan sigifikan dari pengaruh dari pemberian ekstrak daun Bryophillum pinnatum dosis I,II,III terhadap jumlah sel B matur. untuk kadar anti dsDNA menunjukkan ada perbedaan yang bermakna kadar pada kelima kelompok sampel dengan Pvalue $=0.000$, dilanjutkan dengan uji LSD dan didapatkan hasil ada perbedaan sigifikan dari pengaruh dari pemberian ekstrak daun Bryophillum pinnatum dosis I,II,III terhadap kadar anti dsDNA. Kesimpulan : pemberian ekstrak daun Bryophillum pinnatum terbukti dapat menurunkan jumlah sel B matur, namun tidak terbukti dapat menurunkan kadar anti dsDNA pada mencit $B A L B / c$ model lupus bunting.
\end{abstract}

Kata kunci : Ekstrak Daun Bryophillum pinnatum; Jumlah Sel B Matur; Kadar Anti dsDNA

\begin{abstract}
Background: Systemic Lupus Erythematosus (SLE) is a chronic autoimmune disease that affects more women, especially at reproductive age. In silico research through molecular docking found that the content of the active compound possessed by the Coco Duck plant (Bryophyllum pinnatum) has the potential to be developed into biosimilar therapy.

Objective: This study aims to look at the role of Bryophillum pinnatum leaf extract on mature B cell counts and anti-dsDNA levels in BALB / c mice in pregnant lupus models.

Method: The research design used was true experimental with a post test only control group design approach. The samples of this study were 20 BALB / c strains of mice, and grouped into 5 groups. Measurement of the number of mature $B$ cells is done by the flowsitometry method and anti dsDNA levels are measured by the ELISA method. Results: The number of mature B cells showed that there were significant differences in the five sample groups with Pvalue $=0.029$, followed by the LSD test and the results showed a significant difference from the effect of the administration of Bryophillum pinnatum leaf extracts dose I, II, III on the number of mature B cells. the anti dsDNA levels showed significant differences in the levels of the five sample groups with Pvalue $=0.000$, continued with the LSD test and the results showed a significant difference from the effect of the administration of Bryophillum pinnatum leaf extracts dose I, II, III to the anti dsDNA levels. Conclusion: Bryophillum pinnatum leaf extract was proven to reduce the number of mature $B$ cells, but it was not proven to reduce levels of anti-dsDNA in BALB / c mice in pregnant lupus models.
\end{abstract}

Keywords: Bryophillum pinnatum Leaf Extract; Matured B Cell Counts; Anti-dsDNA Levels 


\section{PENDAHULUAN}

Systemic Lupus Eritematosus (SLE) adalah suatu penyakit autoimun kronis yang lebih banyak diderita oleh wanita dan dapat menyebabkan kerusakan pada beberapa organ. Penyakit ini terutama menyerang wanita usia produktif dengan perbandingan wanita: laki-laki yaitu 9:1 (Varghese, 2011). Penyakit SLE yang kebanyakan terjadi pada wanita usia reproduksi seringkali menimbulkan masalah kesehatan terutama pada masa kehamilan yang dapat membahayakan kondisi ibu dan janin (Kwok, 2011). Komplikasi yang terjadi pada penderita SLE selama kehamilan ini perlu mendapatkan perhatian yang serius karena keterlambatan diagnosis dan terapi dapat menyebabkan terjadinya kematian ibu dan janin (Wallace, 2007). Kemajuan teknologi dalam bidang kedokteran saat ini telah dapat mengembangkan berbagai macam terapi baru untuk penyakit auto imun dengan menggunakan agen biologis (Merril, 2010). Terapi agen biologis adalah terapi dengan menggunakan antibody monoklonal yang ditargetkan pada suatu molekul, seperti sitokinataureseptor pada sel tertentu untuk menginaktivasi kerja molekul tersebut. Terapi agen biologis telah dibuktikan pada uji preklinis maupun trial klinis dapat menghamba tperkembangan penyakit dan mencegah terjadinya komplikasi pada berbagai penyakit auto imun, seperti arthritis reumatoid dan SLE (Rocatello, 2011 dan Fitri, 2015)

Pengobatan standar pasien SLE saat ini ditujukan untuk menekan respon imun dan inflamasi yang berlebihan dengan menggunakan obat-obat imuno supresan. Pengobatan yang relative sama diberikan pada penderita lupus baik sebelum maupun selama masa kehamilan. Namun terapi tersebut harus mempertimbangkan risiko kejanin(Fitri, 2015). Obat-obat imuno supresan umumnya diberikan dalam jangka waktu yang lama atau bahkan seumur hidup sehingga sangat perlu mempertimbangkan efek samping yang ditimbulkan (Wallace, 2007). Oleh karena itu, diperlukan suatu terapi alternatif yang memiliki efektivitas yang serupa dengan agen biologis. Beberapa tahun terakhir ini telah dikembangkan suatu model terapi baru yang disebut dengan terapi biosimilar.

Penelitian in silico melalui molecular docking (Kusworini, 2014) menemukan bahwa kandungan senyawa aktif yang dimiliki oleh tanaman cocor bebek (Bryophyllum pinnatum) memiliki potensi untuk dikembangkan menjadi terapi biosimilar. Senyawa aktif pada daun cocor bebek yaitu bryophillin A, bryophillin B, 
bryophillin $C$, dan bryotoxin $B$ memiliki kemampuan untuk melakukan docking dengan afinitas energi yang besar pada $B$ cell activating factor (BAFF) dan a proliferation inducing ligand (APRIL) yang merupakan ligan utama yang berperan dalam maturasi dan proliferasi sel B serta produksi autoantibodi pada SLE(Mackay, 2009 dan Liu, 2011). Oleh karena itu, tanaman tersebut berpotensi untuk menjadi obat kompetitif inhibitor untuk mencegah ikatan ligan BAFF dan APRIL pada reseptornya sehingga diharapkan dapat menurunkan aktivasi sel B yang berdampak pada menurunnya produksi autoantibodi yang berperan pada SLE yang salah satunya adalah antibodi anti double strain Deoxy Nucleic Acid(dsDNA).

\section{METODE PENELITIAN}

\section{Jenis Penelitian}

Jenis penelitian ini adalah penelitian kuantitatif dengan Rancangan penelitian yang digunakan adalah true experimental (eksperimental sesungguhnya) dan pendekatan post test only control group design.

\section{Waktu dan Tempat Penelitian}

Penelitian ini dilaksanakan di Laboratorium Fakultas Kedokteran Universitas Brawijaya. Penelitian ini dilakukan pada Bulan Maret sampai September 2016.

\section{Subjek Penelitian}

Hewan coba yang digunakan adalah mencit bunting galur BALB/c betina (20-25 gr) usia 10-12 minggusejumlah 20 ekor yang diperolehdari LPPT Universitas Islam Negeri (UIN) Malang, mencit dikelompokkan menjadi 5 kelompok : kelompok control negatif (mencit bunting sehat), kelompok control positif (mencit bunting lupus), kelompok perlakuan I (mencit bunting lupus + ekstrak Bryophillumpinnatum dosis $10,5 \mathrm{mg} /$ hari), kelompok perlakuan II (mencit bunting lupus + ekstrak Bryophillumpin natum dosis $21 \mathrm{mg} /$ hari), dan kelompok perlakuan III (mencit bunting lupus + ekstrak Bryophillumpin natum dosis $42 \mathrm{mg} / \mathrm{hari}$ ). Mencit di adaptasi selama 7 hari, kemudian diijeksipristan $0,5 \mathrm{mg}$, setelah lebih dari 12 minggu dan mempunyai hasil tes ANA yang positif maka mencit dibuntingkan. Pada hari ke 9 gestasi mencit diberi ekstrak daun Bryophillumpinnatum.

\section{PROSEDUR}

\section{Mencit Lupus Bunting}

Pembuatan mencit model lupus dilakukan dengan cara menyuntikan pristan $0,5 \mathrm{ml}$ secara intra peritoneal satu kali selama penelitian dan dilakukan setelah masa aklimasi selesai yaitu setelah hari ke 7 . 
Prose pembuntingan dilakukan dalam 3 tahap : LeeBoot effect, pheromon effect, dan whitten effect. Mencit dikawinkan dengan mencit jantan dengan perbandingan 2 mencit betina dan 1 mencit jantan selama 1 malam. Plug vagina di periksa pada pagihari. Betina yang menunjukkan plug vagina postif $(\mathrm{VP}+)$ segera dipisahkan dengan jantan. Hari terlihatnya VP+ dianggap sebagai hari ke 1 gestasi11

\section{Proses Ekstraksi}

Daun Bryophillumpinnatum kering diperoleh dari UPT Materia Medika Batu Malang. Daun kering Bryophillum pinnatum diproses dengan metode maserasi dengan pelarut etanol $96 \%$ di laboratorium farmakologi FKUB. Hasil ekstraksi berupa ekstrak kental (pasta) dan diencerkan dengan normal saline

\section{Pemberian Ekstrak}

\section{Bryophillumpinnatum}

Esktrak Bryophillumpinnatum yang telah di encerkan diberikan secara oral dengan sondek husus selama 10 hari/masa kehamilan mencit dengan dosis 10,5 $\mathrm{mg} /$ hari, $21 \mathrm{mg} /$ hari, $42 \mathrm{mg} /$ hari.

\section{Prosedur Pemeriksaan Jumlah Sel B}

\section{Matur}

Secara keseluruhan prosedur pewarnaan dilakukan berdasarkan prosedur dari pabrik Biolegend. Selanjutnya dilakukan koneksi dengan komputer dan flowsito meter yang diatur sesuai dengan parameter yang akan dianalisa. Sampel yang sudah diinkubasi dengan anti bodi ditambah 300 iL PBS dan ditempatkan pada kuvetflowsitometer. Selanjutnyadipilih acquire dan flowcytometer untukmenghitung jumlah sel total serta jumlah sel yang terdeteksi oleh label antibodi. Hasil yang diperoleh selanjutnya diolah dengan BD cellquest Pro.

\section{Prosedur Pemeriksaan Kadar Anti dsDNA}

Pemeriksaan kadar dsDNA dilakukan setelah tikus diterminasi dan diambil serum darahnya sebanyak1 cc dan kemudian diakukan pemeriksaan dengan menggunakan metode ELISA. Kemudian langkah kerjadi sesuaikan dengan panduan yang tertera dalam kit antibodi Mouse antidouble strain DNA (dsDNA $\operatorname{lgG}$ ) ELISA kit,katalog nomor CSB-E11194 m (96 tes).

\section{Data, Intrumen, dan Teknik Pengumpulan Data}

Untuk pengukuran jumlah sel B matur, dilabel dengan pewarnaan antibodi FITC Antimouse $\mathrm{CD}^{+} 9^{+}$dan PE Antimouse $\mathrm{CD} 22^{+}$. Pemeriksaan kadar dsDNA dilakukan dengan menggunakan kit antibodi Mouse anti-double strain DNA (dsDNA $\operatorname{lgG}$ ) ELISA kit,katalog nomor CSB-E11194 m (96 tes). 


\section{Teknik Analisis Data}

Analisa Data yang digunakan dalam penelitian ini adalah menggunakan software SPSS 17.0. Data diuji normalitas dan homogenitas, dilanjutkan dengan teknik analisis data yang dilakukan untuk mengetahui perbedaan tekanan darah dan kadar albumin urin pada kedua kelompok dengan menggunakan uji beda independent t test

\section{HASIL PENELITIAN DAN} PEMBAHASAN

1.Pengaruh Ekstrak Daun Bryophillum pinnatum Terhadap Jumlah Sel B Matur Yang Terbentuk Pada Mencit BALB/c Model Lupus Bunting Dengan ANOVA dan dilanjutkan dengan LSD

a. Dari hasil uji anova didapatkan nilai probabilitas sebesar $0.029(<0.05)$ dan dapat disimpulkan bahwa terdapat minimal satu pasang kelompok dari kelima kelompok di atas yang memiliki perbedaan jumlah Sel B matur yang signifikan

b. Hasil Uji LSD

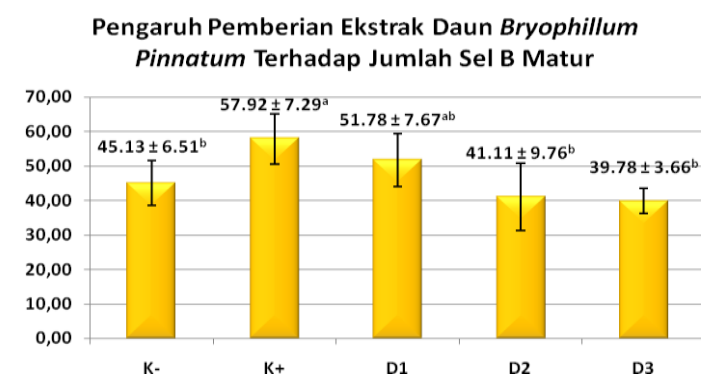

kelompok perlakuan yang diberikan ekstrak daun Bryophillum pinnatum dosis 42 $\mathrm{mg} /$ hari menghasilkan persentase sel B matur yang paling rendah dan berbeda signifikan dengan kelompok kontrol positif.

\section{Pengaruh Ekstrak Daun Bryophillum} pinnatum Terhadap Kadar Anti dsDNA Pada Mencit BALB/c Model Lupus Bunting Dengan ANOVA dan dilanjutkan dengan LSD

a. Dari hasil uji anova didapatkan nilai probabilitas sebesar $0.000(<0.05)$ dan dapat disimpulkan bahwa terdapat minimal satu pasang kelompok dari kelima kelompok di atas yang memiliki perbedaan kadar Anti dsDNA yang signifikan

b. Hasil Uji LSD

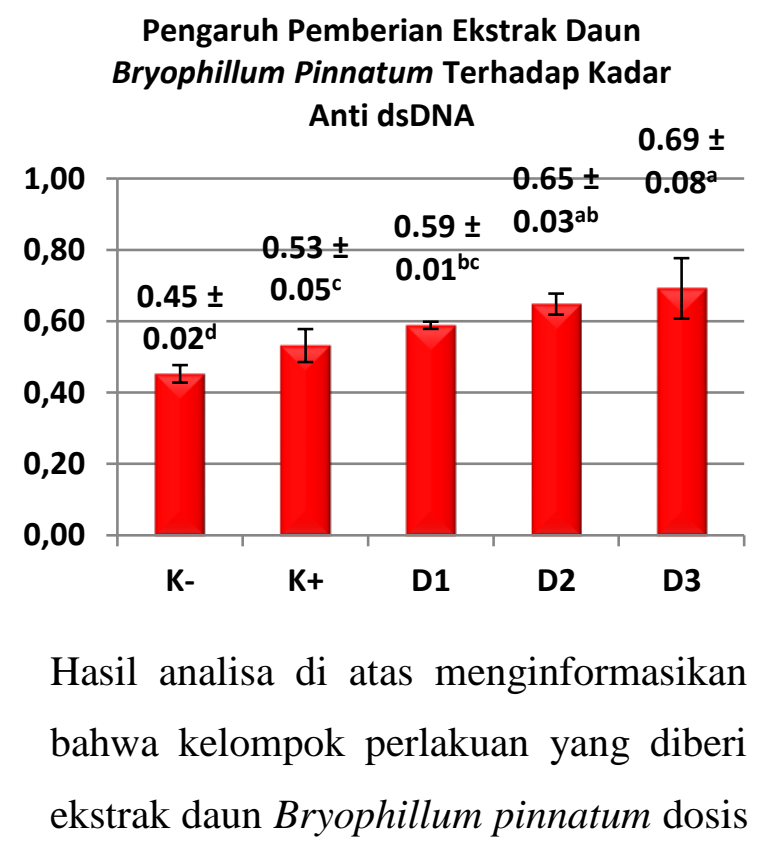


$42 \mathrm{mg} / \mathrm{hari}$ paling optimal dalam meningkatkan kadar anti dsDNA dan berbeda signifikan dengan kelompok kontrol positif, kontrol negatif, dan kelompok perlakuan yang diberi ekstrak daun Bryophillum pinnatum dosis 10.5 $\mathrm{mg} /$ hari.

\section{PEMBAHASAN}

\section{Pengaruh Ekstrak Daun}

Bryophillumpinnatum Terhadap Jumlah

\section{Sel B Matur}

Dari penelitian ini didapatkan hasil jumlah sel B matur pada kelompok control positif lebih tinggi secara signifikan dibandingkan dengankelompokkontrolnegatif. Hal serupa juga ditunjukkan oleh hasilpenelitian yang dilakukanterhadap 30 mencit BALB/c yang dibagi kedalam dua kelompok perlakuan (kelompok mencit SLE yang diberi induksi pristan dan kelompok control sehat). Dari penelitian tersebut didapatkan hasil persentasi jumlahsel B pada kelompok mencit yang diinjeksi pristan lebih tinggi secara signifikan dibandingkan dengan kelompok control (Kalim, 2014). Mekanisme pristan yang dapat menginduksi SLE dimungkinkan karena kemampuannya dalam mengiduksi sel dendritic plasmasitoid (pDC) untuk menginduksi IFNtipe I (Pace, 2010). Pristan secara eksklusif mampu menginduksi IFN tipe satu melalui jalurTLR7. IFNtipe I juga ditemukan memiliki peran dalam proses kerja dari system imun adaptif. Pace et al. (2010) menemukan bahwa IFN tipe I khususnya $I F N-\alpha$ memiliki kemampuan untuk menginduksi APC yang mampu menurunkan fungsi Treg dan meningkatkan fungsi sel Th (Giordani, 2009). IFN- $\alpha$ juga meningkatkan aktivasi sel $B$ naif dan produksi antibody (Postal, 2013). Pengaruh peningkatan hormone dalam kehamilan khususnya estrogen diketahui juga dapat meningkatkan jumlah sitokin proin flamasi, termasuk sitokindari Th2 yang berhubungan dengan peningkatan aktivitas dari sel B. Hasil penelitian ini juga menunjukkan bahwa ada pengaruh pemberian ekstrak daun Bryophillumpinnatum terhadap jumlah sel B. Berdasarkan hasil penelitian, maka didapatkan ada perbedaan bermakna antara rerata jumlah sel B pada kelompok control positif dibandingkan dengan kelompok perlakuan (pemberian ekstrak daun Bryophillumpinnatum dosis $10,5 \mathrm{mg} / \mathrm{hari}$, $21 \mathrm{mg} / \mathrm{hari}$, dan $42 \mathrm{mg} / \mathrm{hari})$. Dari hasil tersebut dapat disimpulkan bahwa ekstrak daun Bryophillumpinnatum dapat menurunkan jumlah sel B matur secara signifikan. Hal ini sejalan dengan hasil penelitian yang dilakukan oleh Kusworini dkk. (2014) yang menyatakan bahwa 
senyawa metabolit Bryophillin A yang terdapat pada daun Bryophillumpinnatum dapat berikatan baik dengan $B$ Cell Maturation Protein (BCMA) dan hal tersebut dapat menghambat terjadinya proses maturase darisel B sehingga sel B matur yang dihasilkan lebih sedikit (Kusworini, 2014).Pada SLE, APC dan fungsi stimulasinya berperan dalam aktivasi selauto reaktif Th1, Th17, dan sel B yang diregulasi oleh factor transkripsi $N F-k B$ sehingga dibutuhkan suatu zat aktif yang dapat menghambat aktivitas $N F-k B$. Hasil penelitian menunjukkan mekanisme quercetin dari ekstrak daun Bryophillumpinnatum dapat menekan sitokin proinflamasi $T N F-\alpha$ dan ekspresi protein melalui down regulasi dari ekspresi gen $N F-K \beta 1$ (Cui, 2006). Analisis lebih lanjut menunjukkan quercetin dapat menurunkan dapat menurunkan aktivitas dari NF-K $\beta$ sehingga akan menghambat autoreaktivitas dari Sel B.

\section{PengaruhEkstrakDaunBryphillumpinna tum Terhadap Kadar Anti dsDNA}

Hasil penelitian ini membuktikan kadar anti dsDNA pada kelompok kontrol positif lebih tinggi secara signifikan dibandingkan dengan kelompok kontrol negatif. Hal ini sesuai dengan hasil penelitian yang menunjukkan bahwa injeksi tunggal 0,5 mL pristan pada mencit BALB/c secara intraperitoneal dapat meningkatkan kadar autoantibodi anti-dsDNA dan ANA pada bulan ke-3 dan bulan ke-4(Satoh, 1996). Studi lain yang dilakukan oleh Satoh et al. (2000) menunjukkan bahwa hampir seluruh strain mencit ternyata memiliki suseptibilitas terhadap munculnya autoantibodi SLE setelah diinduksi oleh pristan, meliputi anti-Sn, anti dsDNA, dan beberapa antibodi lainnya (Sacher, 2004). Beberapa penelitian lain menunjukkan terdapat hubungan timbal balik antara kadar hormon estrogen dengan sistem imun. Estrogen mampu mengaktivasi sel B poliklonal sehingga mengakibatkan produksi autoantibodi berlebihan pada pasien SLE. Hasil penelitian ini juga menunjukkan bahwa pemberian ekstrak Bryphillum pinnatum dapat meningkatkan kadar anti dsDNA pada mencit kelompok perlakuan yang diinjeksi pristan dan diberi ekstrak daun Bryophillum pinnatum.Rerata kadar anti dsDNA semakin meningkat sejalan dengan semakin tingginya dosis yang diberikan. Hal ini berbanding terbalik dengan hasil temuan sebelumnya pada penelitian ini, yaitu semakin menurunnya jumlah Sel B matur jika dosis Bryophillum pinnatum ditambahkan. Dari hasil penelitian ini diasumsikan bahwa docking Bryophillum pinnatum yang menyekat ikatan BAFF dan APRIL dengan reseptornya (BAFF-R, TACl, BCMA) dapat menghambat proses maturasi sel $\mathrm{B}$, 
tetapi juga memicu aktivasi sel B dengan menginduksi molekul-molekul asesori seperti CD21, CD40, CD 45, CD81 yang berperan dalam proses aktivasi sel B, serta sitokin proaktivasi lainnya seperti IL-2 (IL2R $\alpha$, IL-2R $\beta$ ), dan IL-21 (IL-21R). Dari hasil penelitian ini, peneliti berasumsi bahwa senyawa metabolit sekunder yang terdapat pada ekstrak daun Bryophyllum pinnatum berfungsi sebagai aktivator pada proses aktivasi sel B yang menyebabkan semakin meningkatnya aktivasi dan diferensiasi sel B menjadi sel plasma sehingga terjadi peningkatan jumlah sel plasma dan diikuti peningkatan produksi antibodi Anti dsDNA

\section{Kesimpulan}

Pemberian ekstrak daun Bryophillumpinnatum terbukti dapat menurunkan jumlah sel B matur, namun tidak terbukti dapat menurunkan kadar anti ds DNA pada mencit BALB/c model lupus bunting

\section{Saran}

Perlu dilakukan uji insilico lanjutan untuk mengetahui sifat dari ikatan afinitas metabolit sekunder Bryophillum pinnatum dengan reseptor dari BAFF dan APRIL, apakah bersifat aktivator atau inhibitor dan perlu dilakukan penelitian lebih lanjut untuk melihat peran ekstrak daun
Bryophillum pinnatum terhadap jumlah sel plasma yang dihasilkan pada mencit model lupus bunting.

\section{UCAPAN TERIMA KASIH}

Penulis mengucapkan terima kasih kepada Kemenristek Dikti yang telah memberi dukungan financial terhadap penelitian ini.

\section{DAFTAR PUSTAKA}

1.Varghese stephy, Crocker Ian, Bruce N Ian \& Tower Clare. 2011. Systemic Lupus Erythematosus, Regulatory $T$ Cells and Pregnancy

2.Kwok L.W, Tam L.S, Zhu TY, Leung Y.Y \& Li EK. 2011. Predictors of Maternal and Fetal Outcomes in Pregnancies of Patients with Systemic Lupus Erythematosus. dipublikasikan dalam jurnal permissions 2011. Diunduh tanggal 07 Juli 2015.

3.Wallace, Daniel J. 2007. The Clinical Presentation of Systemic Lupus Erythematosus; Differential Diagnosis and Disease Association. In: Wallace, Daniel J, Hahn, Bevra Hannahs. Dubois' Lupus Erythematosus 7th ed. California: Lippincott Williams \& Walkins

4.Merrill, J.T., Neuwelt, C.M., Wallace, D.J., et al. 2010. Efficacy and safety of rituximab in moderately-to-severely active systemic lupus erythematosus: the randomized, double-blind, phase II/III systemic lupus erythematosus evaluation of rituximab trial. Arthritis and Rheumatism, 62(1): 222-33

5.Rocatello, D., Sciascia, S., Rossi, D., et al. 2011. Intensive short-term treatment with rituximab, cyclophosphamide and methylpredinisolone pulses induces remission in severe cases of SLE with nephritis and avoids further immunosuppresive maintenance therapy. Nephrology Dialysis Transplantation. 26: 3987-92 
6.Fitri, L.E., Sardjono, T.W., Rahmah, Z., Siswanto, B., Kusworini, H., Dachlan, Y.P. 2015. Low Fetal Weight is Directly Caused by Sequestration of Parasites and Indirectly by IL-17 and IL-10 Imbalance in the Plasenta of Pregnant Mice with Malaria. Korean J Parasitol. 53(2): 189-196

7.Kusworini dan Mirza Z.P. 2014. Pengujian Ekstrak Cocor Bebek Terhadap Maturasi dan Apoptosis Sel B Mencit Balb/c Diinduksi Pristane Sebagai Pengembangan Terapi Biosimilar Untuk Lupus. Fakultas Kedokteran Unviversitas Brawijaya

8.Mackay, F., Schneider, P. 2009. Cracking the BAFF code. Nat Rev Immunol, 9: 491-502

9.Liu, Z., Davidson, A. 2011. BAFF and selection of autoreactive B cells. Trends Immunol, 32: 388-394

10.Kalim, H. 2014. Pengembangan Hewan Model Lupus Eritematosus Sistemik Menggunakan Mencit Balb/C Yang Diinduksi Pristane. Fakultas Kedokteran Unviversitas Brawijaya

11.Pace L, Vitale S, Dettori B, et al. 2010. APC activation by IFN- $\alpha$ decreases regulatory $\mathrm{T}$ cell and enhances Th cell functions. J Immunol .184(11): 5969-79

12.Giordani L, Sanchez M, Libri I, Quaranta MG, Mattioli B, Viora M. 2009. IFN-alpha amplifies human naive B cell TLR-9-mediated activation and Ig production. J Leukoc Biol. 86(2): 261-71

13. Postal, M., Peliçari, K. O., Sinicato, N. A., Marini, R., Costallat, L. T. L., Appenzeller, S., 2013. Th1/Th2 cytokine profile in childhoodonset systemic lupus erythematosus. Cytokine. 61(3): 785-791

14.Cui, G. M., Liu, G., Liu, W., Kan, B., Mao, Y. Q., Wei, Y. Q. 2006. [Experimental study of pristane-induced murine lupus model]. Sichuan da xue xue bao. Yi xue ban Journal of Sichuan University. Medical science edition, 37 (2): 309-312
15. Satoh, M., Hamilton, K.J., Aimani, A.K., Dong, X., Wang, J., Kanwar, Y.S., Reeves, W.H. 1996. Autoantibodies to ribosomal P antigens with immune complex glomerulonephritis in SJL mice treated with pristane. J immunol, 157(7): 3200-3206

16. Sacher, R.A., McPherson, R.A. 2004. Tinjauan Klinis Hasil Pemeriksaan Laboratorium edisi 11, diterjemahkan oleh Pendit BU; Wulandari D. Protein serum dan plasma. Penerbit Buku Kedokteran EGC, Jakarta. ;311-9 